\title{
THE LIFECYCLE VALUE OF FACILITY MANAGEMENT PROFESSIONALS
}

\author{
Benjamin R. Thompson ${ }^{1}$ and Hala Nassereddine ${ }^{2}$
}

\begin{abstract}
As the construction industry focuses its effort on adopting lean principles to eliminate waste during project execution, an argument exists to reorient the industry's lean journey to start with the operations phase. The continued absence of Facility Managers in the design process will prolong the inefficiencies of current project delivery methods. The failure to adapt planning processes to include Facility Management (FM) professionals prevent a total lean transformation of the construction industry. A question then arises about what value-adding activities exist in the operations phase to impact lifecycle costs of future projects. Using insights gained from existing literature, this paper assesses the lifecycle value of the FM industry and applies it to the Architecture, Engineering, and Construction industry to maximize the delivered value. This paper identifies five interactions between FM and Lean Principles that justify the integration of FM professionals into the development phase of a facility's lifecycle. This paper is limited to the scope of FM and design and does not account for external pressures and requirements caused by contractual agreements, fiscal requirements, or regulatory guidance.
\end{abstract}

\section{KEYWORDS}

Facility management, lean, stakeholder integration.

\section{INTRODUCTION}

As the construction industry focuses its effort on adopting lean principles to eliminate waste through the construction phase, there is an argument to reorient the industry's lean journey to start with the operations phase (Pilanawithana and Sandanayake 2017). Approximately $80 \%$ of any given project's life cycle costs occur during the operations phase (Wang et al. 2013). Facility management (FM) professionals through developed understanding of the relationships that exist between buildings, owners, businesses, and occupants can identify value-adding activities to benefit future projects. As a project progresses from conception through construction, the ability for the project team to affect change decreases whereas the cost for rework and design changes increases (Bascoul 2017). Integrating FM professionals early on during the project's lifecycle enables the project team to make informed design decisions to deliver value to both the owner and end-users and increase the long-term value of the project.

This paper's purpose is to demonstrate the added value that FM professionals can provide during the early development phases of a project's lifecycle. Furthermore, using lean philosophies and principles this paper will present a theoretical framework for

Graduate, Civil Engineering Department, Construction Engineering and Project Management, University of Kentucky, Lexington, KY 40506, USA, + 1931 801-8524, benjamin.r.thompson11@gmail.com, orcid.org/0000-0001-7241-3195

2 Assistant Professor, Civil Engineering Department, Construction Engineering and Project Management, University of Kentucky, Lexington, KY 40506, USA, +1 859 257-1687, hala.nasserddine@uky.edu, orcid.org/0000-0001-8870-5854 
integrating FM into the design phases to increase value for the customer and end-users. The paper is organized into three sections: (1) background (history and definitions of FM, and proposed application to some of Toyotas 14 Management Principles), (2) the literary review with discussion points, and (3) conclusion.

\section{BACKGROUND}

\section{A Brief History of FaCility Management}

To understand the importance of integrating FM professionals into the design process, it is necessary to understand the history and definitions surrounding the profession. Previous studies have defined FM and Bascoul (2017) compiled a detailed history, definitions repository, and list of critical areas of responsibility. A summary of Bascoul's findings is outlined below.

The birth of FM is attributed to Florence Nightingale, who made recommendations for the built environment and linked it towards patient recovery (Finch 2010). This led to the development of "evidence-based design," which can be described as the interpretation of evidence to make design decisions. The term FM was coined in the 1960s (Finch 2010) or 1970s (Haynes and Price 2002). Researchers began to study how workers interact with their workspace and noticed that offices of the time were too rigid and did not support changes in the organizations they supported (Bascoul 2017). The introduction of information technologies then enabled employers, workers, and workspaces to have fluidity, requiring FM to transform into a dynamic management process (Bascoul 2017).

\section{DEFINITIONS}

The literature review showed that there is no single definition for FM. Becker and Steele (1990) defined FM as "... [the discipline] responsible for coordinating all efforts related to planning, designing, and managing buildings and their systems...to enhance the organization's ability to compete successfully in a rapidly changing world." Barrett and Baldry (2003) stated that FM is "an integrated approach to operating, maintaining, improving, and adapting the buildings and infrastructure of an organization in order to create an environment that strongly supports the primary objectives of that organization" (Bascoul 2017). Wiggins (2014) noted that "FM is about taking control, adding value, supporting the business, ensuring that space and working environments enhance not impeded the productivity of the core activity and the staff." With regards to areas of responsibility, this research assumed three articles to provide the most encompassing definitions. Becker and Steel (1990) wrote "buildings, systems, equipment, furniture," compared to Atkin and Brooks (2015) highlighted "services and support infrastructure" (Bascoul 2017). Whereas Wiggins (2014) stated that FM professionals "[maintained] a supporting role...control of non-core activities... and [enabled businesses]." With this baseline understanding of FM history, how it has been defined, and the areas of responsibility FMs have been assigned the following conclusion can be drawn: FM professionals are facility users, business partners, and building caretakers. The experience gained from sustained operations across a wide definition of tasks provides invaluable insight that can better define the voice of the customer for design teams, constructors, and owners.

\section{The TOYOTA WAY}

Liker (2004) compiled the lessons learned and observations from studying Toyota manufacturing plants, their workers, and leaders. The foundation of "The Toyota Way" 
is the detailed definition and real-world examples of the Toyota Automobile Corporations 14 Management Principles. Though, all 14 principles support a comprehensive lean transformation, the FM industry primarily interacts with five. First, the inclusion of FM professionals in the early stages of a project's lifecycle mirrors the call to "base your management decisions on a long-term philosophy, even at the expense of short-term financial goals (Liker 2004)." From the previous section, a reliable FM professional should understand the interactions between structures and building systems, therefore; they can help the project team to "only use reliable, thoroughly tested technology that serves your people and processes (Liker 2004)." Thirdly and fourthly, a total lifecycle approach to the project team "[demonstrates] respect [to] your extended network of partners and suppliers by challenging them and helping them improve," and enables teams to "make decisions slowly by consensus, thoroughly considering all options... (Liker 2004)." Finally, tracing the lessons learned through the construction hand off and operation of like facilities pushes the industry to "become a learning organization through relentless reflection and continuous improvement (Liker 2004)."

\section{LITERATURE REVIEW AND DISCUSSION}

This research started with a review of relevant literature, focusing on: FM, lean practices, and project lifecycle. The literature review was followed by a comparison of industry and lean values, and derivation of an FM metric that theoretically measures the effectiveness of FM integration and estimates the operations and maintenance costs.

\section{FM in Programming AND Design (PD)}

FM professionals build expertise through repetition and daily interactions with businesses, employees, and building systems. The talent and knowledge of FM professionals is often overlooked during the programing and design phases of project development. Table 1 is a compilation of findings from various authors concerning the role of FM professionals in programing and design, respectively.

Table 1: The role of the FM during Programing and Design.

\begin{tabular}{|c|c|c|}
\hline Phase & Sources & Key Take Away \\
\hline $\begin{array}{l}\text { Programing/ } \\
\text { Consulting }\end{array}$ & $\begin{array}{l}\text { Bascoul (2018) } \\
\text { and Pilanawithana } \\
\text { and Sandanayake } \\
\text { (2017) }\end{array}$ & $\begin{array}{l}\text { FM professionals know the behaviors, preferences, and activities of building users. They } \\
\text { know what designs and infrastructure does and does not meet the building user's needs. } \\
\text { Furthermore, FM professionals know the costs associated with utilities and other supporting } \\
\text { infrastructure. They can anticipate spatial requirements based on occupant routines. The FM } \\
\text { professional's experience is a potential value source during concept development. }\end{array}$ \\
\hline \multirow[t]{2}{*}{ Design } & \multirow{2}{*}{$\begin{array}{l}\text { Fatayer et al. } \\
(2019), \text { Islam et } \\
\text { al. (2017), Meng } \\
\text { (2013), } \\
\text { Pilanawithana } \\
\text { and } \\
\text { Sandanayake } \\
\text { (2017), and } \\
\text { Tucker and } \\
\text { Masuri (2016). }\end{array}$} & $\begin{array}{l}\text { FM professionals perform an evidence based advisory role during design through personal } \\
\text { experience and interactions with building users. Their tactic knowledge on the operation of } \\
\text { maintainability of buildings enables them to understand the balance between the occupant, } \\
\text { the built environment, and the natural environment. The combination of experiences alludes } \\
\text { to a responsibility to advise building owners and the design team on future implications of } \\
\text { energy, maintenance, and operational costs. During the design phase, they can perform } \\
\text { performance evaluations and identify performance indicators that shape the FM strategy. }\end{array}$ \\
\hline & & $\begin{array}{l}\text { FM professionals "should be able to make the client aware that proper physical design of } \\
\text { facilities has direct consequences for the operation..." By identifying and addressing } \\
\text { problems early in the project's lifecycle, the FM professional pulls value using the voice of } \\
\text { future customers; the facilities end-users. Again, the FM professionals experience-based } \\
\text { advice could enable designers to provide safer, healthier, more aesthetically pleasing, and } \\
\text { flexible workspaces, all the while avoiding unnecessary decisions. }\end{array}$ \\
\hline
\end{tabular}

The purpose of early FM integration is to reduce waste during the design, construction, and operating phase by reducing over-processing (over designing of spaces, excessively complex utility, or information technology systems) and defects. FM professionals can provide cost effective recommendations when selecting supporting infrastructure. The recommendations may include methods in which the architects and engineers can 
integrate sustainable designs and systems to decrease costs over the project life cycle (Bascoul 2018; Pilanawithana and Sandanayake 2017). Integrating the FM professional provides the added long-term benefit of building in maintainability and sustainability (building in quality) - with respects to customer needs - must be considered from concept through design. "This will lead to the enhancement of the building's occupant comfort level, a drop in maintenance expenditure, and in turn drop the life cycle cost of the facility." (Fatayer et al. 2019). Meng (2013) explained that the primary concern of building owners is the value of money, more importantly the value of money over time. By integrating the FM professional early in the design process, it is possible for the owner to reduce operating and maintenance costs. In their study, Fatayer et al. (2019) showed that early integration of FM professional has a high probability of decreasing 60-90\% of HVAC and plumbing defects, and up to $30 \%$ of architectural and structural defects. There is also a mild probability that electrical defects could be reduced by $30-90 \%$

The study conducted by Islam et al (2017) originally intended to explore the impact FM professional has on sustainability. The results of the Islam et al (2017) survey suggest that there are cost benefits when including FM professional experience to determine the maintainability, constructability, and occupant satisfaction (comfort) during the design phase. Additionally, the integration of FM into the construction industry can "lead humanity's quest for sustainability," (Islam et al 2017) which is as an altruistic goal for modern businesses. To put some numbers on the survey results, over $75 \%$ of respondents estimated a savings of $20 \%$ of the project costs can be realized if FM professionals are included in the design process. Almost $100 \%$ of respondents agree that maintainability is a critical factor to consider during programing and design. Authors stated that the metrics and expertise for the "quest for sustainability" lie with FM professionals, and their integration into programing and design is how value is added.

A proposed method for theoretically measuring FM integration as a function of sustainability is through comparing energy requirements to the average source energy use intensity (EUI) of comparable facilities. The US Department of Energy (DOE) defines source EUI as the amount of energy required to operate a building as a function of its size (EnergyStar 2020). For the following example, statistics regarding energy requirements published by Australian DOE in 2012 is used as the numerator (Guide 2012).

Fraction of Performance Efficiency in Design $=\sum$ Estimated Annual Energy Requirements by System Type (kBtu/Sq. Ft) / Building type source EUI (kBtu/Sq. Ft)

Fraction of Performance Efficiency in Design for an Office Building: (45.396 kBtu (HVAC) + $29.1 \mathrm{kBtu}$ (Lights) + 25.608 kBtu (Equipment) + $4.656 \mathrm{kBtu}$ (Elevators) + $1.164 \mathrm{kBtu}$ (Water) + 10.476 kBtu (Other)) $/ 116.4 \mathrm{kBtu}=1$

Design teams using this measurement should consult FM professionals when planning materials, spatial requirements, and Mechanical, Electrical, Plumbing, and Fire Protection (MEP-F) systems to adopt solutions that provide a fractional value below 1 . Theoretically, this would mean that the facility is designed to out-perform comparable facilities, therefore reducing the long-term costs associated with energy use.

Few literatures highlight the barriers to FM integration during the programing and design phases of the project lifecycle. Jensen (2008) offered a simple conclusion; design teams perceive FM professionals to lack qualified experiences to enhance the design process. Jensen (2008) concluded that the lack of competencies, whether through education or certifications, and the lackluster of the FM profession drives the poor perception. Bu Jawdeh (2013) added budget restrictions and the designer or owners lack 
of interest in and understanding of the FM professional's experience-based advice. The lack of standardization across the FM profession, regarding systems of record or within certification, could be to blame. However, this literature review did not seek out the performance gaps between owners, occupants, and end-users, and FM professionals. The performance gap's existence warrants a holistic study to define value added activities and professional expectations to help align the professions of management, ownership, and design.

Lean construction aims to increase collaboration through Integrated Project Delivery (IPD), the Lean Project Delivery System, or introduction of technologies such as Building Information Modeling (BIM). "Without FM-DP integration, the [FM professionals] and other stakeholders work separately due to the fragmentation of the [development process]." Collaboration of trades and stakeholders must include FM professionals. This integration is a value adding activity resulting in improved facility lifespan and increasing the cost benefit of early coordination activities (Tucker and Masuri 2016). FM integration should result in buildings that best fit the user's needs; that are more attractive to clients; easier to commission, control, manage, and maintain; are more cost effective; and are adaptable to changes in customer needs (Meng 2013).

\section{FM In CONSTRUCTION AND ClOSE-OUT (CCO)}

Pilanawithana and Sandanayake (2017) conducted a literary survey and interviews of 10 FM professionals to investigate the role FM plays during a building's life cycle. The primary benefit of involving the FM professional during the construction and close-out phase is to provide continuity from what was planned to what was executed. This includes as built drawings, and changes made to supporting infrastructure: information technology and MEP-F systems. This information provides the first input for the FM to begin developing a preventative maintenance schedule. Furthermore, involving the FM professional during construction provides structural and infrastructure familiarity, and enables the FM professional to conduct quality assurance with respects to specifications of utility supply and installation (Pilanawithana and Sandanayake 2017). In addition to the collection of as-built drawings, the FM professional must collect warranties for infrastructure equipment installed to understand the warranty and liability periods, and the operations and maintenance manuals for that equipment. These documents enhance the FM professional's ability to forecast maintenance schedules and create flexibility for adaptation once building users are identified.

Considering and involving the FM professional during construction and close-out is not a non-value-added activity. Integration into the construction process provides project familiarity, accurate drawings and schematics, and documentation all enable the FM professional to increase the value of services provided. Additionally, the FM professional's understanding of occupant behaviours and maintenance procedures allows the possibility for FM professionals to perform a unique version of quality assurance and control through the lens of a customer and as an individual user.

\section{FM IN BUILDING OPERATION (BO)}

FM, in the roughest definition, has existed since people have occupied structures. It is in our nature to care for the items and property entrusted to us; and human ingenuity drives us to continually improve our environment. As businesses and structures evolved the FM profession struggled to maintain pace (Tay and Ooi 2001). This section is aimed at identifying areas of improvement within the FM industry, with the goal of linking challenges with integration opportunities. 
Jylhä and Junnila (2013) presented four points explaining how the FM industry has failed to deliver value to occupants and owners. First, the FM professional receives the work but does not execute it, this results in a chain of information passing where facts are lost or diluted over time. Secondly, FM professionals have the responsibility but not the power to deliver and meet customer satisfaction. Jylhä and Junnila (2013) stated that FM professionals do not have a mechanism to process, track, and perform quality assurance on given tasks. Thirdly, end-users - businesses - have different needs and are treated differently. The business may pass responsibility for FM work to the employee, introducing stress, and increasing the risk for dissatisfaction. Lastly, the FM discipline strives to achieve a lean transformation, but the profession focused on optimizing subprocesses instead of the entire delivery process (Jylhä and Junnila 2013). Liker (2004) wrote about the Canada Post Corporation's lean transformation and summarized that their success was predicated on an environment of continuous improvement, focused leadership, and the adoption of lean philosophies. In that respect, FM will arguably continue failing to deliver value until its professional culture is changed.

The study executed by Jylhä and Junnila (2013) highlighted violations of lean principles and processes. First, they show that FM, as it is executed now, fails to define value, develop a value stream, and make it flow from the customer. Secondly, the failure to follow the steps towards lean thinking, results in the inability to create continuous flow, surface problems, use pull systems, use visual controls, and use standardized processes. The root cause of these problems is the lack of FM integration into the programming and design phases of the project lifecycle. As previously stated, if FM professionals are integrated during the programming, design, and construction phases they are able provide valuable input into the customers real needs in comparison to their perceived needs. Additionally, FM professionals can steer decisions with respects to integrating sustainable features and systems to prolong the lifecycle. Lastly, early integration builds project familiarity and enables FM professionals to develop management strategies before the facility is commissioned.

\section{THE LEAN MANAGEMENT APPLICATIONS}

This section of the paper will relate the responsibilities, goals, and benefits of early FM integration to five of the Toyota Management Principles outlined by (Liker 2004).

Principle 1. Base your management decisions on a long-term philosophy, even at the expense of short-term financial goals. Alexander (1994) described the evolution of the FM discipline as the belief in inspire people to do their best by improving the processes that manage workplaces to support the businesses effectiveness and long-term goals. In comparison, Liker (2004) condensed Toyota's first principle to base decisions on longterm philosophy to Edward Deming's "constancy of purpose." Liker (2004) states that Toyota's adaptation of a "constancy of purpose" allows the automobile corporation to make short- and long-term decisions, while anchoring their workers around a shared purpose. In this regard, the construction industry's lean journey must adopt a "constancy of purpose" and consider the FM discipline to pull value from the end users.

Principle 8. Use only reliable, thoroughly tested technology that serves your people and processes. One of the strongest arguments for involving the FM during design is maintainability. $95 \%$ of respondents responded positively (agree or strongly agree) in the survey conducted by Islam et al (2017) that maintainability should be considered when designing structures. Bascoul (2017) noted that disregarding FM experiences with supporting infrastructure results in design inefficiencies and maintenance related 
problems. Liker (2004) does not conclude that using reliable technologies means to disregard new technologies. Instead, he states that Toyota only introduces new technologies once they have been thoroughly vetted by its workers. He goes on to explain that Toyota will weigh the costs and benefits of adding the new technology before fully adopting it. Similarly, architects, engineers, and contractors should incorporate experience and advice that FM professionals possess to meet the customer's needs. If a new technology is requested or considered, by the owner, a FM professional should be consulted to conduct a cost-benefit analysis, provide a list of suitable alternatives, and make long-term recommendations to the owner and design team.

Principle 11. Respect your extended network of partners and suppliers by challenging them and helping them improve. This principle truly applies throughout the construction project's life cycle. Toyota maintained this principle despite its growth and popularity because relationships matter, furthermore the health of the network matters. (Liker 2004). Liker (2004) developed a supply chain hierarchy of needs to demonstrate the sensitivity of business relationships between producers and suppliers. Figure 1 is an adaptation of Liker's (2004) diagram and describes the need hierarchy of FM integration. If the construction industry aims to increase long-term value for their customers through the adoption of lean philosophies, then the network of partners surrounding the industry should be considered and developed.

Principle 13. Make decisions slowly by consensus, thoroughly considering all options; implement decisions rapidly. "Make decisions slowly by consensus" is the key phrase of principle 13. Toyota prefers a decision-making process that is characterized by group consensus and management approval. Toyota places value in the effort teams put into evaluation process during the early stages of design. Their teams analyze all possible engineering and manufacturing issues, and pass "study drawings" (books that include sketches and lists of problems and potential solutions) throughout their team to ensure all team members fully understand the scope, constraints, limitations, and risks before making or recommending a decision (Liker 2004).

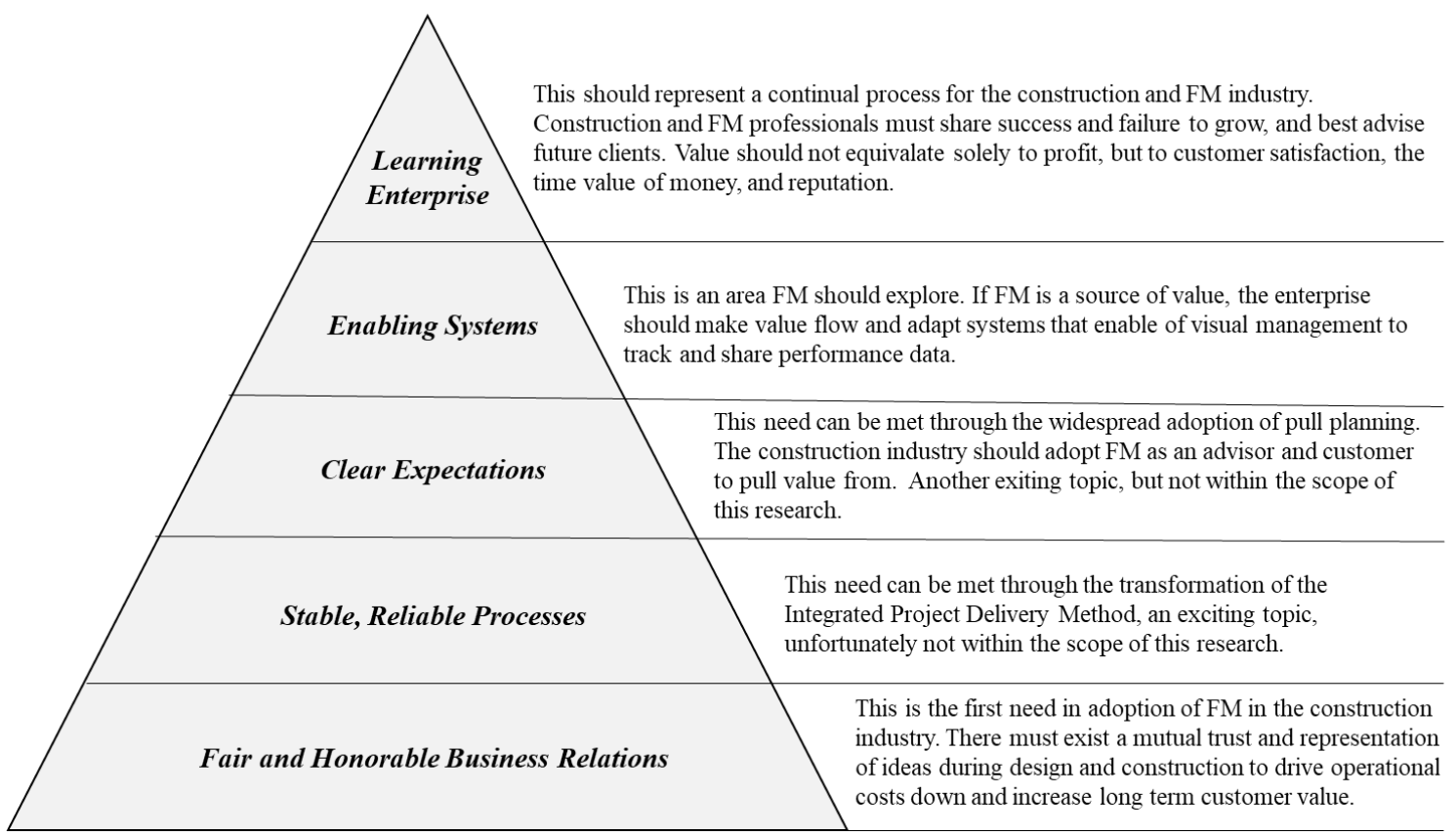

Figure 1: FM Integration Hierarchy of Needs (Adopted from Liker 2004, Figure 17-1

Supply Chain Need Hierarchy). 
The construction industry is slowly adopting this principle through the development of the Last Planner ${ }^{\circledR}$ System and adoption of IPD. However, these tools should be updated to incorporate FM professionals and capture building operational experience to pull value through the design and construction phases.

Principle 14. Become a learning organization through relentless reflection and continuous improvement. "[The learning organization is] where people continually expand their capacity to create the results, they truly desire, where new and expansive patterns of thinking are nurtured, where collective aspiration is set free, and where people are continually learning how to learn together." (Senge 1990, cited by Liker 2004). The top of Figure 6 states that a learning enterprise should represent a continual process for the construction and FM industries. Contrary to popular thought, organizations do not only learn when they succeed; instead, failure encourages comprehensive reflection and organizational learning. Importantly, more can be said about an organization that assumes responsibility for its failures and grows from them. “...errors [are] opportunities [to learn]. ...the organization takes corrective actions and distributes knowledge about each experience broadly. Learning is a continuous companywide process...." (Liker 2004). Not only is creating a learning organization a continual process and the $14^{\text {th }}$ lean management principle, it can be adopted to the Deming Cycle; Plan - Do - Check - Act. (Liker 2004). Figure 2 is an adaptation of the PDCA Cycle to depict how and when the construction and FM industries can encourage continual learning.

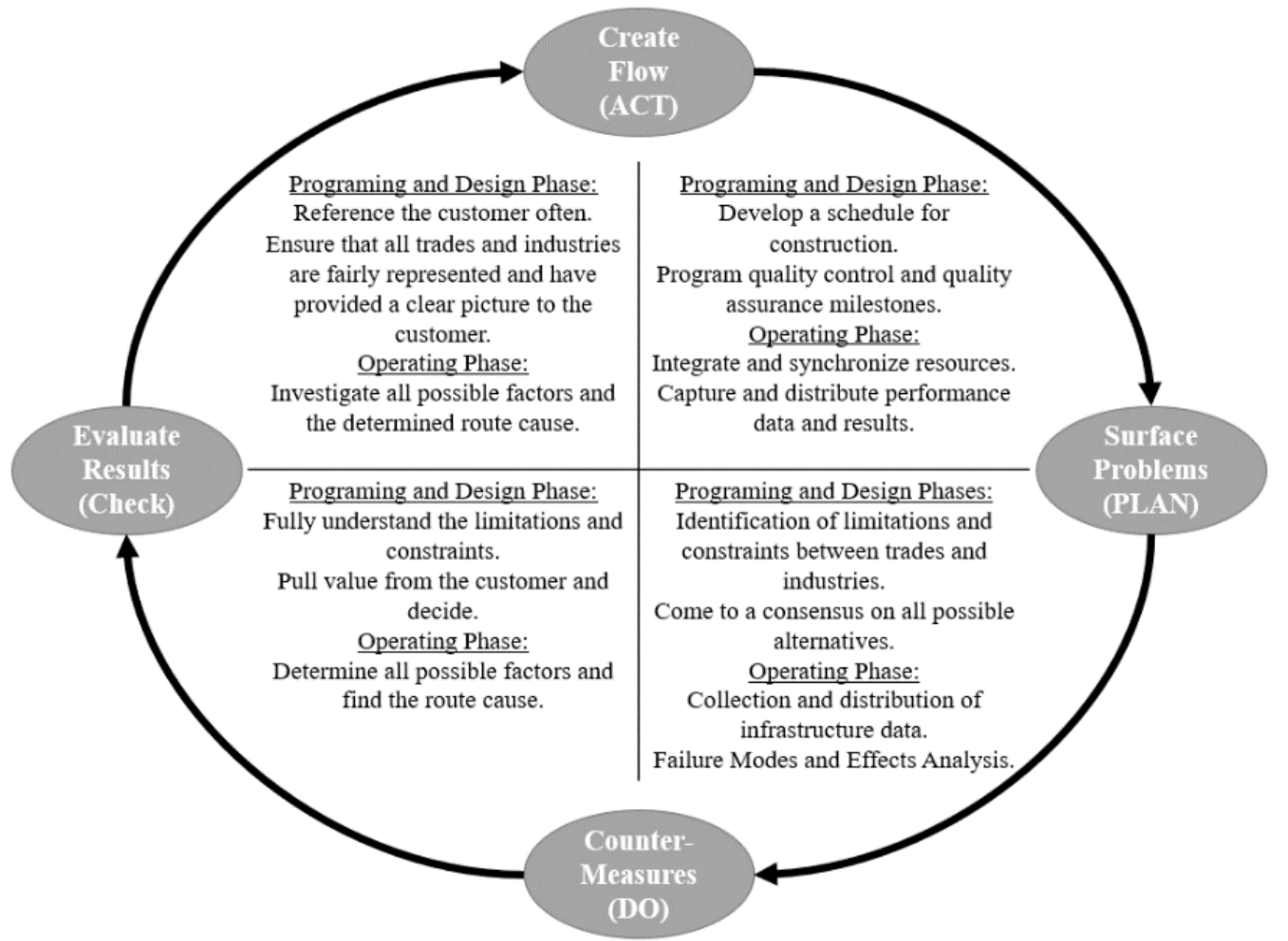

Figure 2: PDCA in Construction (Adapted from Liker 2004, Figure 20-5: Creating Flow and PDCA).

\section{CONCLUSIONS}

FM is a value adding member to the construction industries lean journey. A new definition of FM can be derived from the description of interactions and responsibilities: a longterm customer responsible for cross organizational coordination, integration, and 
synchronization of operational, maintenance, and improvement resources, who adds value to building users - and their businesses - by eliminating waste and providing predictability throughout the management process. Though FM professionals typically deliver value after a facility is commissioned, their understanding of how buildings and organizations interact empowers them to provide feedback during the project programing and design. Ideally, the value of FM in the development phases should be measured through observation of three like construction projects, one where the FM professional was involved during programing and planning only, one where the FM professional was involved during programing, planning, and construction (to perform FM related QA/QC), and one with no FM involvement. This study should span from programing through the first 3-5 years of operation. Researchers should collect data regarding the time and costs of rework (either in design or during construction) that relate to MEP-F systems and sustainability. Following the structures commissioning, researchers should monitor the buildings energy requirements and collect feedback from occupying businesses and personnel. These information requirements would objectively determine the cost-benefit of early FM integration.

\section{REFERENCES}

Alexander, K. (1994). “A Strategy for Facilities Management.” Facilities, 21(11), 269274.

Bascoul, A. M. (2017). Managing Project Structural Complexity by Integrating Facility Management in Planning, Designing, and Execution of High-End Facility Upgrades (Doctoral dissertation, UC Berkeley).

Bascoul, A.M., Tommelein, I.D., Tillmann, P., and Muxen, S. (2018). "Towards Facility Management Participation in Design: A UCSF Case Study.” In: Proc. 26th Annual Conference of the International. Group for Lean Construction (IGLC), González, V.A. (ed.), Chennai, India, pp. 505-515. doi.org/10.24928/2018/0209. Available at: www.iglc.net.

Becker, F. and Steele, F. (1990), "The total workplace", Facilities, 8(3), 9-14. doiorg.ezproxy.uky.edu/10.1108/EUM0000000002099.

$\mathrm{Bu}$ Jawdeh, H. M. (2013). Improving the integration of building design and facilities management (Doctoral dissertation, University of Salford).

Fatayer, F.A., Hassanain, M.A., Abdallah, A., Al-Hammad A.-M. (2019). "Investigation of facilities management practices for providing feedback during the design development and review stages." International Journal of Building Pathology and Adaptation, 37(5), 597 - 614.

Finch, E. (2010) "Florence Nightingale: Pioneer of Facility Management." In W070Special Track 18th CIB World Building Congress May 2010 Salford, United Kingdom, 132-139.

Guide to Best Practice Maintenance and Operation of HVAC Systems for Energy Efficiency (January 2012), Pages 36-37. Retrieved April 30, 2020, from https://www.environment.gov.au/system/files/energy/files/hvac-factsheet-energybreakdown.pdf.

Haynes, B. and Price, I. (2004), "Quantifying the complex adaptive workplace", Facilities, 22(1/2), 8-18. doi-org.ezproxy.uky.edu/10.1108/02632770410517906.

Islam, R., Mohamed, S.F., Amin, A.B., Nazifa, T.H. (2017). "Designing of Facilities Management Sustainable Parameters for Improving Operational Efficiency." Journal of System and Management Sciences, 7(4), 53-78. 
Jensen, P. A. (2008). Integration of Considerations for Facilities Management in Design. In Design Management in the Architectural Engineering and Construction Sector: CIB W096 Architectural Management \& TG49.

Architectural Engineering (pp. 191-199). Rotterdam: CIB. (CIB Reports; No. 319).

Jylhä, T., Junnila, S. (2013). "Learning from lean management - going beyond inputoutput thinking." Facilities, 31(11/12), 454-467.

Liker, J. (2004). “The Toyota Way: 14 Management Principles from the World's Greatest Manufacturer." McGraw - Hill, New York.

Meng, X. (2013). "Involvement of Facilities Management Specialists in Building Design: United Kingdom Experience." Journal of Performance of Constructed Facilities, 27(5), $500-507$.

Pilanawithana, N.M., Sandanayake, Y.G. (2017). "Positioning the facilities manager's role throughout the building lifecycle." Journal of Facilities Management, 15(4), 367 -392 .

Tay, L., Ooi, J.T.L. (2001). "Facilities Management: A “Jack of All Trades?” Facilities, 19(10), 357-362.

Tucker, M., Masuri, R.A. (2016). "The rational to integrate facilities management into the development process." Property Management, 34(4), 332-344.

Wang, Y., Wang, X., Wang, J., Yung, P., \& Jun, G. (2013). Engagement of facilities management in design stage through BIM: framework and a case study. Advances in Civil Engineering, 2013.

What is energy use intensity (EUI)? (n.d.). Retrieved April 30, 2020, from https://www.energystar.gov/buildings/facility-owners-and-managers/existingbuildings/use-portfolio-manager/understand-metrics/what-energy.

Wiggins, J. M. (2014). Facilities manager's desk reference. Retrieved from http://ebookcentral.proquest.com.

Womack, J. P., Jones, D. T. (1996). Lean thinking: banish waste and create wealth in your corporation. New York: Simon \& Schuster. 